\title{
Community Perceptions for Geoconservation of a Coastal Area in Rio de Janeiro, Brazil
}

\author{
Silvania Avelar • Kátia L. Mansur • Sylvia C. Anjos • \\ Gisele F. Vasconcelos
}

Received: 31 October 2013 / Accepted: 22 July 2014 /Published online: 9 August 2014

(C) The European Association for Conservation of the Geological Heritage 2014

\begin{abstract}
We collected socio-environmental data from the inhabitants of a coastal area in the State of Rio de Janeiro, Brazil, in order to investigate the local knowledge about environmental, economic and cultural particularities of the area and the main human activities that impact the environment. Community perceptions from 11 localities in the Região dos Lagos were evaluated. The data analysis can help in the development of specific geoconservation activities for the study area, which is located in the aspirant Geopark 'Costões e Lagunas do Rio de Janeiro'. This initiative of considering community perceptions can help to maintain and protect local geological sites, raise public awareness of environmental matters and help to manage the development of the new Geopark. Furthermore, it can also contribute to the sustainable development of the area and to the planning of effective policies to sustain progress. Taking into consideration the answers and needs of the interviewed communities, the key topics requiring geoconservation activities in the study area are land use planning and biodiversity, urban mobility, continuous monitoring strategy, environmental awareness, wastewater, urbanisation, geotourism, sense of place, waste and economical activities.
\end{abstract}

Keywords Geoconservation - Community perceptions · Geopark · Sustainable development

S. Avelar $(\bowtie) \cdot$ G. F. Vasconcelos

ETHZ, Geological Institute, Sonneggstrasse 5, 8092 Zurich,

Switzerland

e-mail: silvania.avelar@erdw.ethz.ch

K. L. Mansur

UFRJ-IGEO, Rio de Janeiro, RJ 21941-916, Brazil

S. C. Anjos

Petrobras E\&P, Rio de Janeiro, RJ 20031-170, Brazil

\section{Introduction}

The variety of non-living nature, i.e. the geological diversity, consists of many processes and environments, which support the variety and robustness of the biodiversity. As such, the geological diversity, or geodiversity, should also be considered as part of successful nature conservation (Huxley 1946; Sharples 1993; Semeniuk 1997). The conservation of geodiversity applied to a specific location, where important Earth's features (geological, paleontological, geomorphological, hydrological and pedological) are protected, preserved and managed, is referred to as geoconservation (Raharimahefa 2012). These Earth's sites that have high scientific, didactic and touristic relevance are called geosites-or geological heritage or geoheritage.

There is a need for an international framework of geoconservation to enhance the value of the heritage of the Earth and to promote the participation of local communities to conserve it. Especially in regions with low economic development and high unemployment and youth migration rates, the potential of geosites still has to be discovered. The new strategy is called Geopark, which seeks to safeguard and sustainably manage landscapes and geological formations, which are key witnesses to the history of life on Earth, thereby stimulating regional economic and cultural development. Geoparks are based upon developing awareness of local communities, such that they themselves can protect the area and generate income for continuing their preservation work. Geoparks serve three main goals: conserving a healthy environment, educating residents and visitors in the Earth sciences and fostering local, sustainable economic development. An area cannot be considered for inclusion in the Global Geopark Network (GGN) unless the area has also a plan for the sustainable development of the people who live there (UNESCO 2002). 
Sustainable development is commonly defined as a development that meets the needs of the present, without compromising the ability of future generations to meet their own needs (WCED 1987). Sustainability promotes environmental protection and economic and social development as interdependent and mutually reinforcing (WSSD 2002). Action programmes should be implemented to cover a variety of themes such as geoconservation, biodiversity, deforestation, urbanisation, environmental pollution, food production, freshwater supply, health and disease, coastal development, rural development and climate change, among others (Wang et al. 2010).

In an effort to plan appropriate activities for geoconservation of the aspirant Geopark 'Costões e Lagunas do Rio de Janeiro' (Mansur et al. 2012), which is being established along the coast of the State of Rio de Janeiro, we assessed the local knowledge of the resident population of a study area and the main human impacts in the area in which the environment is being neglected. Interviews were conducted with residents, in order to gather socio-ecological information about the region and the current threats to it. Responses were analysed in terms of perception and awareness of environmental concepts, pollution sources, economical activities, existing tourism and changes in the local ecosystem. We investigated aspects of cultural identity ('sense of place') and the connection between human development and nature's capacity to support such development.

Considering the local knowledge of different communities, we identified the main thematic areas for the geoconservation planning and sustainable development in the Geopark. We can apply the list of key topics to find a simple measure of how sustainable is the development of a locality for achieving Geopark goals, i.e. education, conservation and geotourism. The score of a locality can provide a powerful tool to support the compliance of goals of a Geopark.

Various studies have been conducted in the coastal area of Rio de Janeiro; for example, Gianella and Fernandez (2007) analyse socio-environmental benefits of tourism in coastal municipalities, Mansur and Silva (2011) assess the performance of the Geological Paths Project, and Teixeira (2012) discusses the degradation of public open spaces resulting from urbanisation. There exist also many sustainability measures. The Environmental Performance Index (EPI) ranks countries on performance indicators tracked across environmental policy goals (EPI 2013). Macedo et al. (2011) proposes the use of a sustainable development index for municipalities of Rio de Janeiro based on data envelopment analysis (DEA) with various performance drivers, such as capacity investment, IGP, sanitation, education and health. CRiSTAL is a project planning tool that helps users design activities that support climate adaptation at community level (IISD 2013b). The appropriate sustainability measure depends on many factors, including the specific needs of the community and type of audience at which the measure report is targeted. This study provides important information to the planning and partners of a Geopark to better define geoconservation strategies according to local needs.

\section{Study Area}

The study area is located in the Região dos Lagos of Rio de Janeiro and, more specifically, in the south of Araruama Lagoon, which is one of the largest permanently hypersaline coastal lagoons in the world. This area is within the aspirant Geopark Costões e Lagunas do Rio de Janeiro, and it comprises the coastal area from Saquarema to Arraial do Cabo (see Fig. 1). The area contains important geological, historical, cultural and archaeological sites of scientific, didactic, ecologic and touristic interest. The study area includes communities living in the municipalities of Araruama (AR), Saquarema (SA) and Arraial do Cabo (AC). More specifically, the following localities were considered: Bacaxá/SA, Basiléia/ SA, Caiçara/SA, Figueira/AC, Monte Alto/AR, Novo Arraial/ AC, Pernambuca/SA, Porto da Roça/AC, Praia Seca/AR, Rio da Areia/AR and Sabiá/AC.

The urban growth and seasonal tourism in Região dos Lagos has triggered the occupation of ecologically protected areas and the removal of natural vegetation (see examples in Fig. 2a, b). This causes a disorderly occupation of the area, especially on the shore of the lakes (see Fig. 3). The seasonal tourism exceeds the capacities of water supply and basic sanitation of the area and brings other consequences such as an increase in the number of vehicles, electrical energy consumption, real estate speculation and pollution in the air, soil and water. The widespread poverty and the bad governance, which hinder the removal of obstacles to good growth, also cause environmental problems.

\section{Methodology}

The environmental protection plan of a Geopark comprises the development of a management plan for specific sectors, such as education, environment, sustainable development, culture and tourism. For the benefit of society and geoconservation, it is important to implement activities appropriate to local needs, for example, the support of economic activities compatible with required local environmental protection and activities oriented towards environmental education and geotourism. In doing so, regional ecosystems can be protected and the quality of life of the local population improved.

In order to gather socio-ecological information about the region and its current threats and to find out information on people's understanding of environmental issues and their experience in the region, interviews were conducted in the study area between January and February 2013. Table 1 shows the 


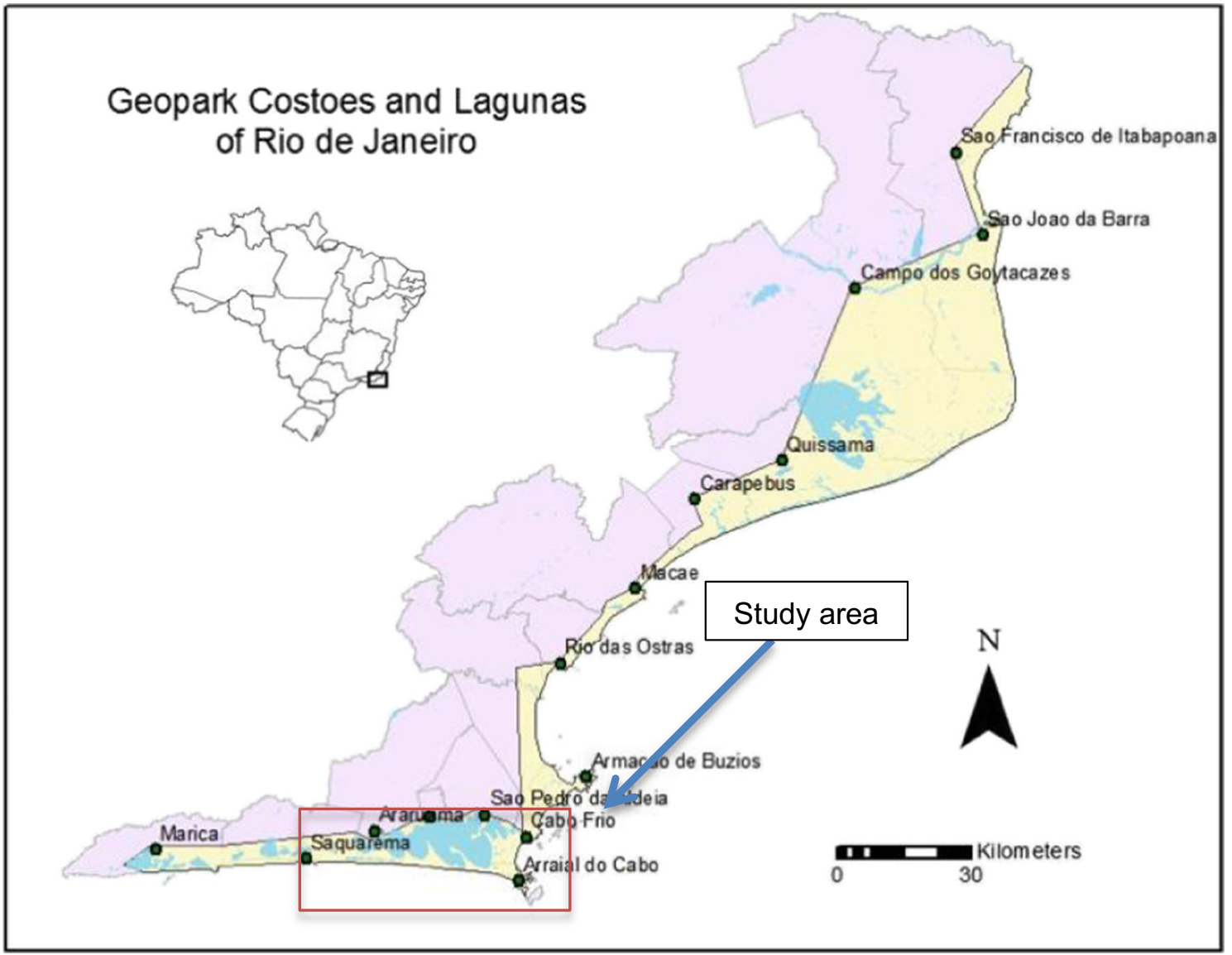

Fig. 1 Location of Geopark 'Costões e Lagunas do Rio de Janeiro' and of study area

overview of tasks by which the data was collected and analysed.

\section{Subjects}

Fifty volunteer participants, aged between 10 and 72, were assessed. In order to ensure that the sample is representative of the population, we balanced the number of female and male respondents for three categories: children (10-18), adults (1969) and elderly people (above 70). The participants for each category were randomly selected in the street, such that a

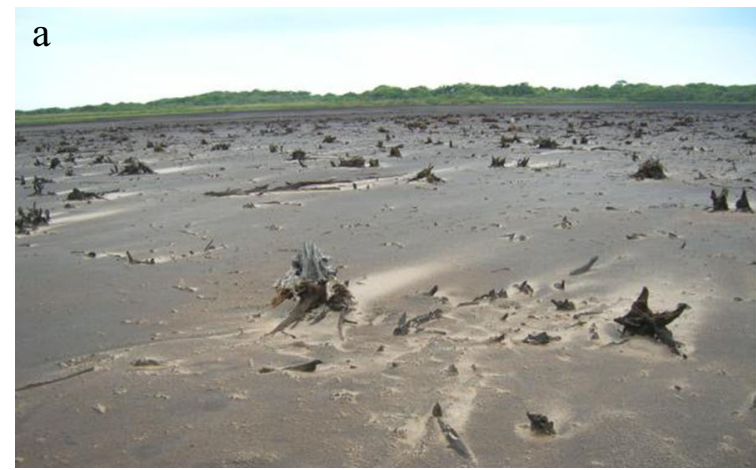

Fig. 2 a Burning on sandbank. b Constructions interfering with dunes similar percentage of children, adults and seniors were obtained. All participants are residents of Região dos Lagos and have varying levels of education, socio-economic classes, familiarity with ecological subjects and local knowledge. Their age and education level are shown in Figs. 4 and 5.

\section{Procedure}

Participants were asked to answer a questionnaire in the presence of an interviewer, who clarified items and took note of answers and relevant comments.

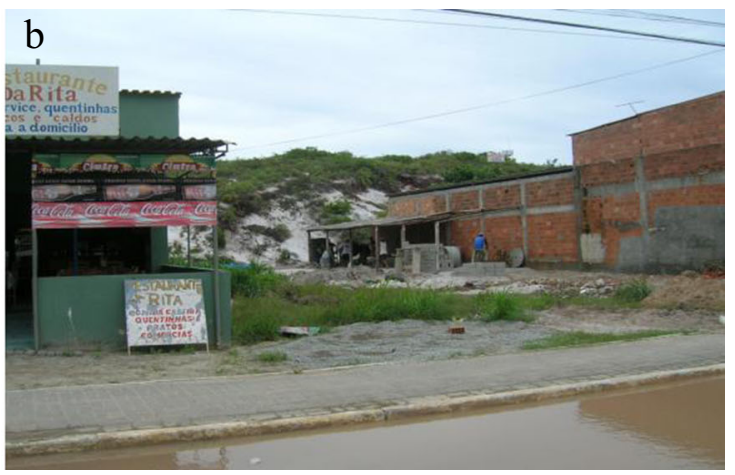




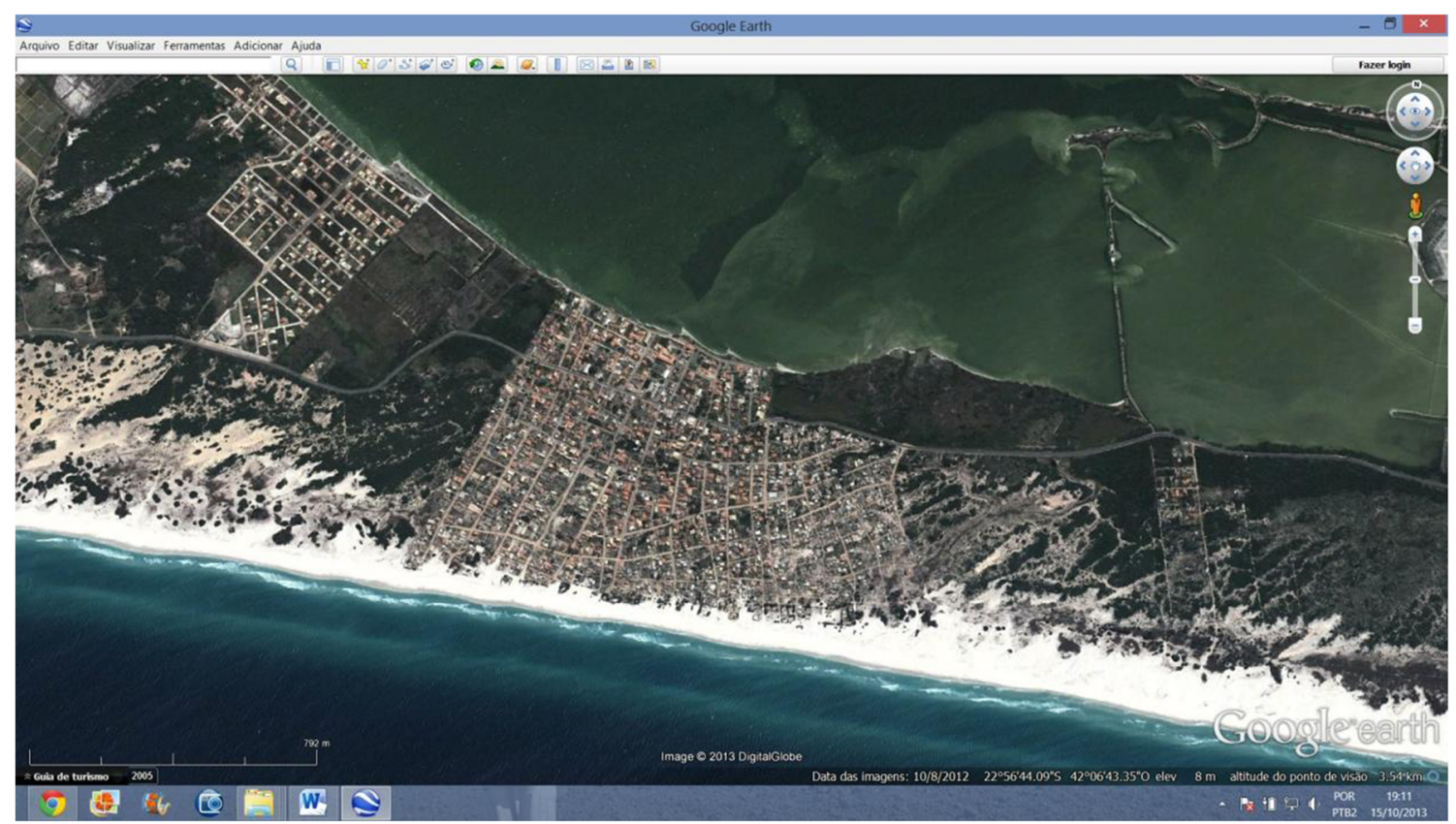

Fig. 3 Occupation on a sandbank in the study area viewed in Google Earth, 2013

Questionnaire A questionnaire form was prepared in order to find out information about people's perceptions of the following issues:

- Existing geosites

- Local pollution sources

- Human activities that impact the environment

- Cultural identity: sense of place

- Environmental resources

- Proliferation of animals or plants in the region

- Changes in the physical environment in the last years

- Climate change

In order to formulate effective questions, the intention was to make the questions as straightforward as possible, to group together questions with similar content, to progress from general questions to specific and to avoid negative questions. One effective way of making sure that questions measure what they are supposed to measure is to test them out in advance, using small focus groups. It is important to keep improving

Table 1 Data collection and analysis

Step 1. Design and test questionnaires

Step 2. Fieldwork: interview, observations

Step 3. Data verification and storage (organize, rectify and index data)

Step 4. Descriptive analysis of data (calculate statistics, identify conservation themes)

Step 5. Create thematic charts (interviewees, conservation themes, localities)

Step 6. Interpretation of results (determine main threats and needs) the questionnaire, as poorly designed questions yield meaningless results.

A pilot form was prepared and tested in October 2012. Our questionnaire had 15 questions, covering five different subject areas: environmental concepts, pollution sources, economical activities, sense of place and future improvements. It also collected the expected benefits listed by participants and additional information relevant for the political management and development of the region.

Interview Interviews were conducted between 15 January and 15 February 2013 in the study area and lasted around $15 \mathrm{~min}$ each. Participants were informed in advance of the purpose of the interview. The interviewer filled out the questionnaire and included relevant additional comments from the participants in the final observation. During the interview, participants were asked to outline the main physical changes that they had noticed in recent years. At the end, they were asked to give their opinion on which benefits they would like to be provided for the region.

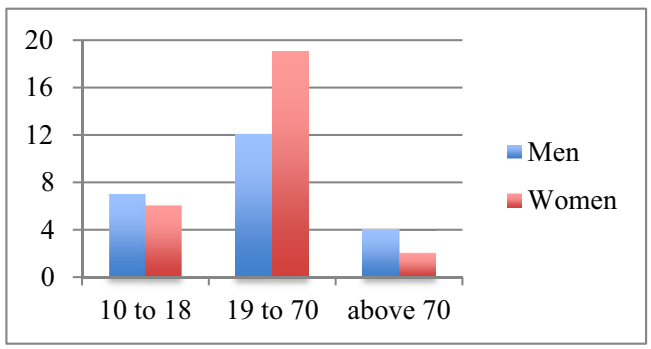

Fig. 4 Age category of interviewees 
Fig. 5 Education level of interviewees

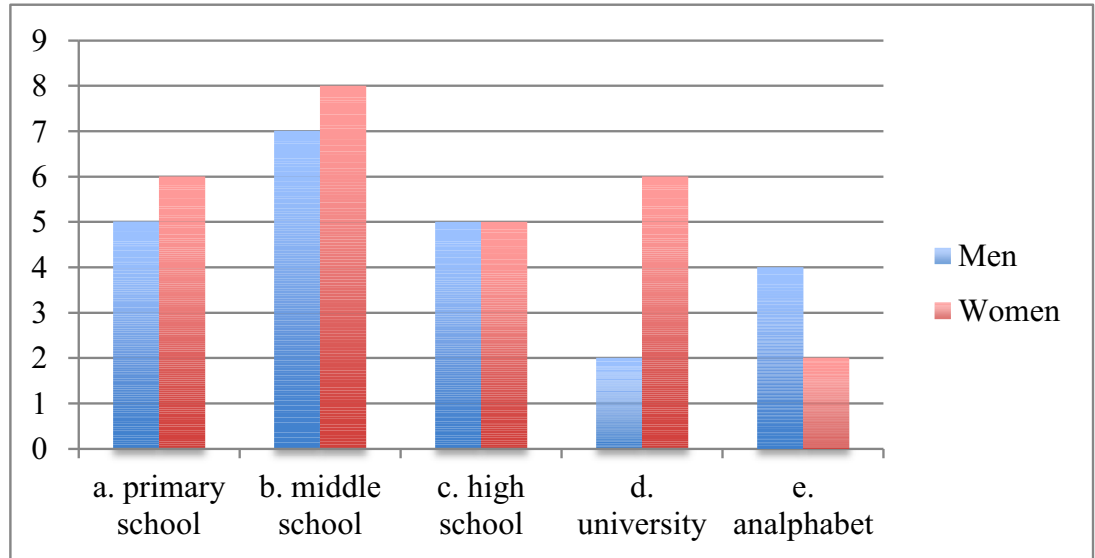

\section{Results}

We got useful feedback from our test participants about environmental issues, sense of place, pollution sources, etc. Based on the participants' answers, we identified key areas by which to state the sustainable development of a region in the Geopark. A sustainable community takes into account and balances the needs of economy, environment and people.

\section{Key Topics to Monitor Sustainable Development}

The most important topics by which to monitor the region's performance on sustainable development while fulfiling the Geopark goals were identified. Activities in all of these topics should be conducted, according to local needs, in order to reach the geoconservation of the Geopark. The key topics with examples of activities can be summarised as follows:

1. Environmental awareness - awareness of concepts of sustainable development, sustainability and existing geosites. Use of education to increase public awareness, e.g. school activities with children (Vasconcelos and Mansur 2011) and government campaigns with adults.

2. Waste - waste can be seen as the major pollution problem in the region. It is expected that an action be taken for waste treatment (collect, separate, recycle, dispose), for example selective waste collection, and also measures for waste reduction, e.g. rational use of materials, change to biodegradable materials, etc.

3. Wastewater treatment - basic sanitation, i.e. safe disposal of wastewater and access to clean drinking water. For example, activities for water and sewage treatment and depollution of lakes.

4. Sense of place - connection to the place, identifying unique characteristics of the place, knowing and protecting the place (human environment) and social and cultural values. For example, gastronomic festival, typical handcrafts exhibition and trade and promotion of traditional knowledge of fishermen.

5. Land use and biodiversity - land area covered by major infrastructure (including buildings, roads, ports) and agriculture, land conversion rates (Avelar and Tokarczyk 2014) and coastal land impacts, protection of bio- and geodiversity, legislation and planning available. For example, activities for control of deforestation, forest burning and pollution.

6. Urbanisation - existing physical planning of urban areas, considering link to land and green areas, improvement of public space. For example, pavement and/or afforestation of roads and development model to recover degraded areas instead of advancing on preserved areas.

7. Economic activities - population involved in local commercial services, products and industries. For example, fishing and local shops.

8. Geotourism - planned touristic activities for promotion of local geosites, seasonal needs considered together with their advantages and disadvantages (difficult topic, as more tourism simply kills tourism). For example, planning of geological paths (e.g. Mansur and Silva 2011) and printed material to be distributed or sold.

9. Urban mobility - available infrastructure fulfils community needs: roads, bus, routes and schedule; urban transport is accessible, safe and secure for all users. For example, availability of more public vehicles of smaller size and a greater variety of routes.

10. Continuity - a monitoring strategy is needed, with interaction and communication with the population, longterm activities, adequate economic and social policies, 'learning by doing' and improving where necessary. There exists a strategy for sustainable development. For example, responsible partnership with the Geopark.

The above conservation elements are complementary to the five evaluation categories of the UNESCO applicant's selfevaluation form for National Geoparks seeking assistance to 
become a member of the Global Network of National Geoparks (GNG 2014). The five evaluative categories are as follows: (I) geology and landscape, (II) management structures, (III) interpretation and environmental education, (IV) geotourism and (V) sustainable regional economic development. Those categories assess mainly the management, policy and marketing aspects of the implementation of a Geopark. The local knowledge of people living in the Geopark area should be taken into consideration, in order to plan specific activities to their needs and to help residents to take an active role in the implementation of the Geopark. Our key topics to monitor sustainable development focus on local people's perceptions of the environment and threats to the aspirant Geopark, i.e. it adds local human aspects to the Geopark action plan in a bottom-up process (see Fig. 6). The ten key topics described previously can be linked to the following evaluative categories of UNESCO: interpretation and environmental education ('environmental awareness'), geotourism ('sense of place, geotourism') and sustainable regional economic development ('waste, wastewater treatment, land use and biodiversity, urbanisation, economic activities, urban mobility, continuity').

\section{Assessing Sustainable Development}

Effective measures are relevant, easy to understand, reliable and based on accessible data. Therefore, we created a simple index to comprise the main goals of a Geopark for a healthy coupled human-nature system at the local community level. The index can help to present the complexity of sustainable development in a simplified form for decisionmakers and for the population in general. The index is only useful as a planning tool, not as a real functional value like other existing indices (IISD 2013a; Macedo et al. 2011) and tools (IISD 2013b).

Taking into consideration the ten key topics previously listed, a simple way to assess the geoconservation state and sustainable development of a locality in the Geopark is to evaluate how many of the previously mentioned topics have activities in progress in the locality and to assign to such topics a positive score. The sustainable delivery of each goal is the foundation of a healthy environment in the Geopark. However, simultaneously achieving positive scores in all key topics is a challenge for the localities in the study area due to their current situation. The score of a locality can be used to prioritise topics for implementing geoconservation activities at the locality and also to promote the geotourism in the Geopark. A locality grade 10 is more prepared to receive tourists than a locality grade 0 , which will not be recommended at all, as they still have to define and implement activities in the topics which have negative scores, within a certain timeframe, which will be agreed with the Geopark management.
Community Perceptions in the Study Area

We analysed the answers and experience of the 50 residents in the study area in Região dos Lagos. Most people do not have information on environmental concepts and existing geosites. From the local knowledge, we found out that land use and biodiversity, together with urban mobility, require urgent long-term solutions in all communities (see Table 2), e.g. control of use and occupation of land, building and zoning, cleansing and protection of areas, effective policies, etc. The inadequate waste collection and waste management systems are also causing serious environmental pollution and health hazards. Wastewater is another serious problem observed in the region. The local geodiversity is threatened by many potentially damaging human activities, which are themselves compounded by poverty, irresponsible management and a lack of awareness by the public and local authorities. Awareness about local cultural identity varied among interviewees.

The gradual degradation of the lake ecosystem in the Região dos Lagos is being hastened by an ever-increasing population, legal and illegal constructions, occupation of work salts, deforestation, unlawful land use, pollution of lagoons, infrastructure overload and problems with both water supply and wastewater treatment (Teixeira 2012). The sanitation infrastructure of the region has deficiencies in the supply of water, sewage collection and the disposal and treatment of solid waste.

In all communities of the study area, we have generally a low grade of sustainable development. Bacaxá is more urbanised than the other localities and the available public services were reflected in the answers derived from its community. In most other localities, people live a more rural life. Many residents in Monte Alto have moved there from other towns. Activities in the specific key topics of geoconservation and sustainable development that are deficient in a locality have to be planned and implemented by the municipal authorities, and as such, negative activities are considered to be threats to the region. Table 2 shows the score of all localities as perceived by their communities as well as the number of deficient localities for each key topic.

The topics for defining geoconservation activities for the study area in the Geopark are shown in their order of relevance in Fig. 7. This result is based on the findings of Table 2. The illegal occupation of public lands, work salts and dunes due to unplanned urbanisation is the main problem for the study area. Urban mobility is another difficult topic, as most of the study area should never have been occupied. The key topics requiring long-term implementation of activities for the geoconservation of the study area are land use planning and protection of biodiversity, better urban mobility and transport infrastructure, and raising public awareness on environmental matters.

The interviewed communities also listed expected benefits for their localities. The goals for the region 
Fig. 6 Conceptual framework for geoconservation and sustainable development at localities of the aspirant Geopark 'Costões e Lagunas do Rio de Janeiro'

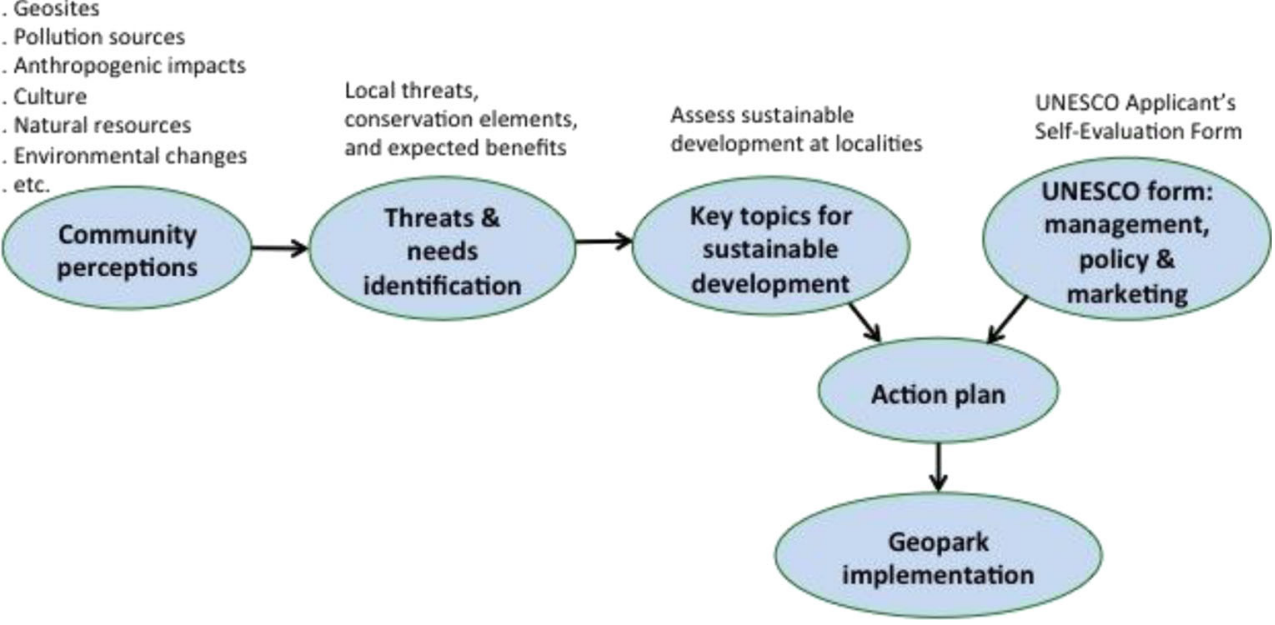

are a continuing, healthy human-nature system with coastal protection, biodiversity, clean waters, local tourism and recreation, sense of place, among others. The expected benefits should also be considered when defining activities for a locality. The listed benefits are the following:

\section{Children}

- Females: more buses, schools, jobs, basic sanitation, security, paved roads, parks, cinema, anti-drug projects for young people;

Males: more leisure, swimming pool, bike paths, waysides.

Adults

- Females: more leisure, buses, pavement of streets and along shoreline, garbage collection, sewage treatment, sport courses, investment in tourism, creation of public awareness about environment;
Males: more leisure, buses, pavement of main streets, sport areas, football field, walking trails, depollution of beaches, industries, security, $24 \mathrm{~h}$ bank, internet, petrol station, kiosk selling newspapers.

Seniors

- Females: clean the lakes;

Males: more leisure for elderly people, buses, public telephones, reforesting, expand the beach along Araruama Lagoon.

\section{Discussion and Conclusions}

A sustainable society works to balance human and economic needs while preserving the health of the natural environment for present and future generations. The

Table 2 Existence of activities in the key topics for geoconservation and sustainable development of localities as perceived by their communities

\begin{tabular}{|c|c|c|c|c|c|c|c|c|c|c|c|c|}
\hline Locality key topic & Bacaxá & Basiléia & Caiçara & Figueira & $\begin{array}{l}\text { Monte } \\
\text { Alto }\end{array}$ & $\begin{array}{l}\text { Novo } \\
\text { Arraial }\end{array}$ & Pernambuca & $\begin{array}{l}\text { Porto da } \\
\text { Roça }\end{array}$ & $\begin{array}{l}\text { Praia } \\
\text { Seca }\end{array}$ & $\begin{array}{l}\text { Rio da } \\
\text { Areia }\end{array}$ & Sabiá & $\begin{array}{l}\text { Total of ' } 0 \text { ' } \\
\text { localities }\end{array}$ \\
\hline $\begin{array}{l}\text { Environmental } \\
\text { awareness }\end{array}$ & 0 & 0 & 0 & 0 & 0 & 0 & 0 & 0 & 0 & 1 & 0 & 10 \\
\hline Waste & 1 & 1 & 1 & 1 & 0 & 0 & 1 & 1 & 1 & 1 & 0 & 3 \\
\hline Wastewater & 1 & 0 & 0 & 0 & 0 & 0 & 0 & 1 & 0 & 0 & 0 & 9 \\
\hline Sense of place & 1 & 0 & 1 & 1 & 0 & 0 & 1 & 1 & 1 & 1 & 0 & 4 \\
\hline $\begin{array}{l}\text { Land use and } \\
\text { biodiversity }\end{array}$ & 0 & 0 & 0 & 0 & 0 & 0 & 0 & 0 & 0 & 0 & 0 & 11 \\
\hline Urbanisation & 0 & 0 & 0 & 1 & 1 & 0 & 1 & 0 & 0 & 0 & 0 & 8 \\
\hline $\begin{array}{l}\text { Economic } \\
\text { activities }\end{array}$ & 1 & 1 & 1 & 1 & 0 & 1 & 1 & 1 & 1 & 1 & 0 & 2 \\
\hline Geotourism & 1 & 0 & 0 & 0 & 0 & 0 & 0 & 1 & 0 & 1 & 0 & 8 \\
\hline Urban mobility & 0 & 0 & 0 & 0 & 0 & 0 & 0 & 0 & 0 & 0 & 0 & 11 \\
\hline Continuity & 0 & 0 & 0 & 0 & 0 & 0 & 0 & 0 & 0 & 0 & 0 & 11 \\
\hline Total of key topics & 5 & 2 & 3 & 4 & 1 & 1 & 4 & 5 & 3 & 5 & 0 & \\
\hline
\end{tabular}


Fig. 7 Relevance of topics for geoconservation activities in the study area

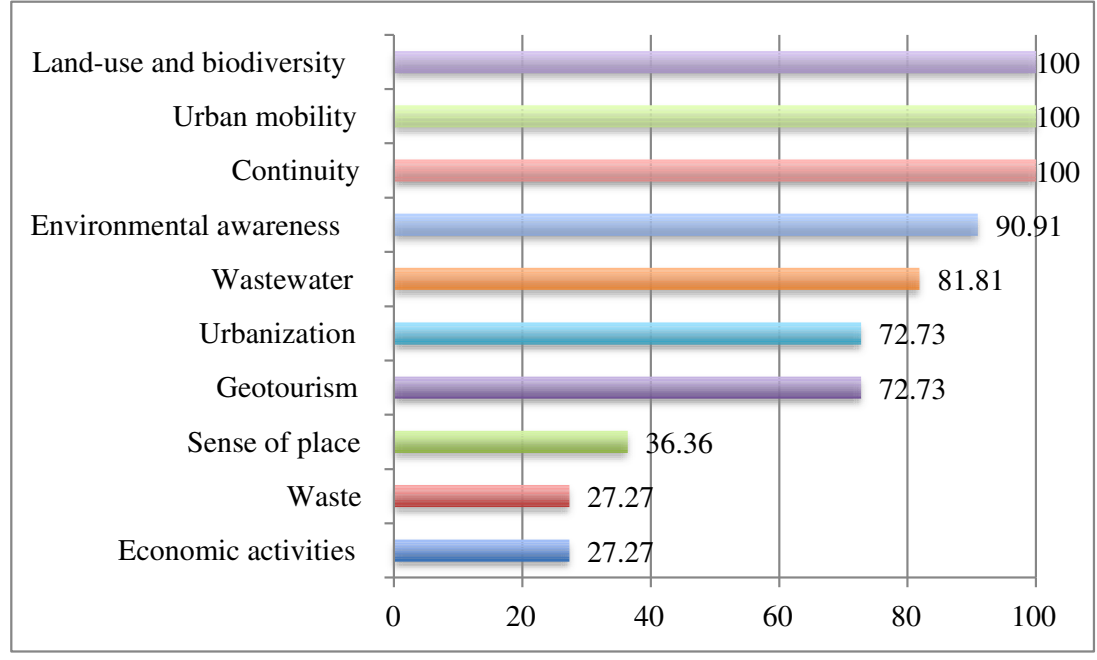

Região dos Lagos of Rio de Janeiro faces the challenges of coupling sustainable development with environmental protection. Protected areas are the main tool to combat environmental crisis and protect the bio- and geodiversity of a region. Geosites should be protected under national conservation legislation. However, this does not yet guarantee conservation, due to infringement of regulations, political instability and lack of funding. It is essential that the local government and population support the creation of a Geopark and are fully involved in the planning of its activities. Public understanding of basic steps of environmental conservation is a must, and as such, education plays a vital role in geoconservation, in order to engage local people and authorities. By developing awareness within the population and Geopark partners, they can themselves protect the area and generate income for continuing the preservation work with the geotourism in the Geopark.

The management of Geoparks should consider local knowledge and assess community perceptions, opinions and needs. Collecting and analysing local data is useful for the conservation planning of the Geopark and to make transparent the potential trade-offs between local human and environmental factors. Taking actions based on the information obtained from interviews can help Geoparks to fulfil their role as active centres for providing a holistic view involving the Earth's history, the natural and cultural environment and raising awareness of man's responsibility to conserve and protect the environment.

The key topics requiring geoconservation activities in the study area in the Geopark Costões e Lagunas do Rio de Janeiro are land use planning and biodiversity, urban mobility, continuous monitoring strategy, environmental awareness, wastewater, urbanisation, geotourism, sense of place, waste and economical activities. Our approach to assess a region's performance on sustainable development is simple. Key topics are counted positively for a locality, based on local people's opinions, whether or not positive activities exist for each key topic. Simultaneously achieving positive scores on all key topics would be difficult at present for the localities in the study area. Trade-offs can occur between topics. Weights can be established for key topics, according to their importance to a given area within the Geopark. Weights can also vary according to location, environmental, social and economic factors. In this case, it is critical to define adequate weight values.

Useful socio-ecological parameters can also be calculated to check in time and space what is present now and what is being left for the future, such as land use, land cover, urbanisation, preserved areas, social groups, etc. In addition, indicators can be defined to monitor pollution sources, population awareness, people's responsibility and cultural identity. As some people find it beneficial to use the web to access Geopark information, another possible next step is to optimize the current questionnaire for the online medium.

Our study is still in its early stages. However, because of the many threats to the geodiversity of Rio de Janeiro's coastal area and the expected increase of tourism in the coming years due to world events, conservation actions should urgently be taken. The assessment encourages that further steps are taken for geoconservation of the aspiring Geopark Costões e Lagunas do Rio de Janeiro. The work is also intended to be a pilot experience to support the acquisition of local knowledge for defining geoconservation activities in other Geoparks.

Acknowledgments This project is part of the research collaboration "Pethros" between Petrobras and ETHZ - Swiss Federal Institute of Technology (no. 200020127327). 


\section{References}

Avelar S, Tokarczyk P (2014) Analysis of land use and land cover change in a coastal area of Rio de Janeiro using high resolution remotely sensed data. J Appl Remote Sens 8:083631 1-14

EPI (2013) Environmental Performance Index. http://epi.yale.edu. Accessed 20 Sept 2013

Gianella LC, Fernandez MA (2007) Atividade Turística em Municípios Litorâneos: Valoração Ambiental de Custos/Benefícios e sua Percepção pela População. Um estudo de caso em Cabo Frio, RJ. In: Branquinho F, Felsenszwalb I (eds) Meio Ambiente: experiências em pesquisa multidisciplinar e formação de pesquisadores. Faperj, pp 93-112

GNG (2014) Global Network of National Geoparks. http://www. globalgeopark.org. Accessed 30 June 2014

Huxley J (1946) UNESCO: its purpose and its philosophy. Paris

IISD (2013a) International Institute for Sustainable Development. http:// www.iisd.org/ measure/compedium. Accessed 30 Aug 2013

IISD (2013b) CRiSTAL — community-based risk screening tool-adaptation \& livelihoods, International Institute for Sustainable Development. http://www.iisd.org/cristaltool/. Accessed 30 Aug 2013

Macedo MAS, Cruz CF, Ferreira ACS (2011) Índice de Desenvolvimento Sustentável: uma Análise Apoiada em DEA para os Municípios do Estado do Rio de Janeiro. Gestão Regionalidade 27(81):19-31

Mansur KL, Silva AS (2011) Society's response: assessment of the performance of the Caminhos Geológicos (Geological Paths) Project, State of Rio de Janeiro, Brazil. Geoheritage 3:27-39

Mansur K, Guedes E, Alves M, Nascimento V, Pressi LF, Costa N, Pessanha A, Nascimento LH, Vasconcelos G (2012) Geoparque Costões e Lagunas do Rio de Janeiro (RJ) - proposta. In:
Schobbenhaus C, Silva CR (eds) Geoparques do Brasil: propostas, vol 1. CPRM, Rio de Janeiro

Raharimahefa T (2012) Geoconservation and geodiversity for sustainable development in Madagascar. Madagascar Conservation \& Development, 7(3). http://dx.doi.org/10.4314/mcd.v7i3.5. Accessed 2 Jul 2013

Semeniuk V (1997) The linkage between biodiversity and geodiversity. In: Eberhard R (ed) Pattern \& processes: towards a regional approach to national estate assessment of geodiversity. Technical series no. 2, Australian Heritage Commission \& Environment Forest Taskforce. Environment Australia, Canberra, pp 51-58

Sharples C (1993) A methodology for the identification of significant landforms and geological sites for geoconservation purposes. Report to Forestry Commission, Tasmania

Teixeira VML (2012) Remaining landscape: public open spaces and urbanization process in a Coastal Region in Brazil. 15th Int. Planning History Society Conference, São Paulo, 15-18 Jul 2012

Unesco (2002) Global Geoparks Network. http://www.unesco.org. Accessed 3 Jul 2013

Vasconcelos G, Mansur K (2011) Environmental education children's books, 10th European Geoparks Conference, 16-20th September. Langesund, Norway

Wang Y, Tobey J, Ngusaru A, Makota V, Bonynge G, Nugranad J (2010) Geospatial information for sustainable development: a case study in coastal East Africa. In: Remote sensing of coastal environments. CRC Press Taylor and Francis Group. Boca Raton

WCED (1987) Our common future, World Commission on Environment and Development. Oxford University Press

WSSD (2002) World Summit on Sustainable Development, United Nations, Johannesburg. http://www.unmillenniumproject.org/ documents/131302 wssd report reissued.pdf 